\title{
Alternative subclinical mastitis traits for genetic evaluation in dairy cattle
}

\author{
E. Kirsanova, ${ }^{1 *}$ B. Heringstad,,${ }^{2,3}$ A. Lewandowska-Sabat, ${ }^{1}$ and I. Olsaker ${ }^{1}$ \\ ${ }^{1}$ Department of Basic Sciences and Aquatic Medicine, Faculty of Veterinary Medicine, Norwegian University of Life Sciences, NO-0102 Oslo, \\ Norway \\ ${ }^{2}$ Department of Animal and Aquacultural Sciences, Faculty of Biosciences, Norwegian University of Life Sciences, NO-1432 Ås, Norway \\ ${ }^{3}$ Geno Breeding and Al Association, NO-2317 Hamar, Norway
}

\section{ABSTRACT}

Chronic subclinical mastitis (SCM), characterized by changes in milk composition and high somatic cell count (SCC) in milk for a prolonged period of time, is often caused by a bacterial infection. Different levels of SCC have been suggested and used as threshold to identify subclinical infection. The aim of this study was to examine different definitions of SCM based on test-day SCC and estimate genetic parameters for these traits and their genetic correlation to milk production. Test-day SCC records from 1,209,128 Norwegian Red cows in lactation 1 to 3 were analyzed. Twelve SCM traits were defined as binary with 2 test-day SCC in a row above SCC thresholds from 50,000 to 400,000 cells/ mL (SCM50, SCM100, SCM150, SCM200, SCM250, SCM300, SCM350, and SCM400), with 3 test-day SCC in a row above 200,000 and 400,000 cells/mL (SCM200_3 and SCM400_3), and the number of days before the first case with SCM50 (D50) or SCM400 (D400). The heritability and genetic correlations were estimated for SCM traits and the mean lactationaverage somatic cell score (LSCS) using linear animal repeatability models. The total mean frequency of SCM ranged from $1.2 \%$ to $51.8 \%$, for different trait definitions, high for low SCC threshold (SCM50) and low for the highest SCC threshold (SCM400_3). For the 2 traits based on number of days, the mean values were 104 (D50) and 117 (D400) days. The mean LSCS was 4.4 (equivalent to around 82,000 SCC). Heritabilities for the 12 alternative SCM traits were low and varied from 0.01 (SCM400_3) to 0.1 (SCM100), whereas for LSCS the estimated heritability was 0.3 and standard error varied from 0.001 to 0.003 . Genetic correlations among the SCM traits ranged from 0.7 (D50 and SCM400) to 1 (SCM350 and SCM400), whereas between SCM traits and milk production the correlation ranged from 0.07 (LSCS) to 0.3 (D400). The standard error for genetic

Received December 5, 2018.

Accepted February 11, 2019.

*Corresponding author: elena.kirsanova@nmbu.no correlations varied from 0.001 to 0.06 . The heritability was low and the genetic correlations were strong among SCM traits. Genetic correlations lower than 1 suggest that the alternative SCM traits are genetically different from LSCS, the trait currently used in genetic evaluations for Norwegian Red. Hence, the alternative traits will add information and improve breeding for better udder health.

Key words: somatic cell count, Norwegian Red, heritability, genetic correlation

\section{INTRODUCTION}

Mastitis is one of the most frequent and costly diseases in dairy cattle, characterized as an inflammatory process in the mammary gland, often with increased SCC in milk (Harmon, 1994). Clinical mastitis (CM) is characterized by clinical symptoms such as severe udder inflammation, whereas chronic subclinical mastitis (SCM) is recognized by changes in milk composition such as high SCC for prolonged periods of time (Harmon, 1994; Østerås et al., 2007). Normal SCC in healthy udder quarters has been reported to be lower than 100,000 cells/mL (Schwarz et al., 2011). High SCC, commonly used to characterize SCM, is defined as more than 200,000 cells $/ \mathrm{mL}$, and will often lead to decreased milk production (Dohoo and Leslie, 1991; Harmon, 1994; Schepers et al., 1997; Østerås et al., 2007; Pantoja et al., 2009). Staphylococcus aureus and Streptococcus agalactiae are known as some of the most common bacteria causing udder inflammation. According to the health status report for Norwegian Red (NR) cows in 2017, S. aureus is the major causative bacterium of mastitis, found to be present in $25.4 \%$ of milk samples (TINE SA, 2017). Somatic cells consist of epithelial cells together with polymorphonuclear leucocytes and macrophages involved in defense against infections in the udder (Miller et al., 1991; Schwarz et al., 2011). Hence, the amount of these cells in milk gives an indicator of the inflammatory process in the udder.

Alternative definitions of the SCC-based mastitis traits have been analyzed previously. Windig et al. 
(2010) defined SCM as binary traits based on whether or not 2 consecutive SCC test days were above 150,000 and 250,000 cells $/ \mathrm{mL}$ by using Dutch herd records from the Nederlands Rundvee Syndicaat. Koeck et al. (2012) defined 7 SCC traits, for different parts of the lactation, for genetic evaluation of mastitis in Canadian Holsteins. Urioste et al. (2012) defined SCM in Swedish Holsteins as number of periods from days in milk $>45$ with $\mathrm{SCC}>150,000$ cells $/ \mathrm{mL}$. de Haas et al. (2008) estimated high genetic correlation (0.98) between SCM, defined as a binary trait $(0 / 1)$, as absence or presence of test-day SCC $>150,000$ cells $/ \mathrm{mL}$ in lactation, and suspicion of IMI. Svendsen and Heringstad (2006) defined SCM traits as present if 2 test days with SCC were above a fixed threshold of 50,000 to 200,000 cells/ $\mathrm{mL}$ and reported genetic correlation among these SCM traits was between 0.89 and 0.92 . Estimated heritability was lower for higher thresholds and ranged from 0.05 to 0.09 across the 3 first lactations.

Which SCC threshold to use to classify chronic SCM is still not clear. Also, most of the literature is on Holsteins, and breed differences have been reported for udder health and immune response (e.g., Begley et al., 2009). Hence, the aim of this study was to examine novel alternative definitions of chronic SCM traits in NR based on prolonged high SCC, and estimate heritability of and genetic correlations among these SCM traits together with their genetic correlation to milk yield.

\section{MATERIALS AND METHODS}

\section{Animals and Phenotypes}

Phenotypic data have been collected routinely in the Norwegian Dairy Herd Recording System since 1978, which is a complete historical database for the NR population that is available for analyses. Records of testday SCC for NR cows with calving in the years 2006 to 2016 were obtained from the Norwegian Dairy Herd Recording System. Data set A with 1,209,128 observations from 701,440 cows with a corresponding pedigree file of $1,473,837$ individuals was used for estimation of variance components and heritability. Records from the first 3 lactations of cows from herd-years with at least 15 NR cows were included. The data set was further restricted to only test-day SCC records from DIM between 21 and 305, and from lactations with 2 or more test day records. Due to computational limitations, a smaller data set B, including information from 2014 to 2016, was used for estimation of genetic correlations. The last data set contained 357,203 observations from 243,556 cows and had a corresponding pedigree file of 933,049 individuals.

\section{Trait Definition and Distribution}

Four SCM traits were defined with the same SCC thresholds of 50,100, 150, and $200 \times 10^{3}$ cells $/ \mathrm{mL}$ as Svendsen and Heringstad (2006). Additional traits with higher SCC thresholds up to $400 \times 10^{3}$ cells $/ \mathrm{mL}$, the highest acceptable level of SCC in bovine milk allowed for human consumption (European Commission Milk Hygiene Directive 92/46, 1992) were also included. Thus, 8 binary SCM traits were defined based on SCC thresholds of $50,100,150,200,250,300,350$, and $400 \times 10^{3}$ cells $/ \mathrm{mL}$ (SCM50, SCM100, SCM150, SCM200, SCM250, SCM300, SCM350, and SCM400, respectively). The SCM50 to SCM400 were set equal to 1 if SCC was above the given threshold at 2 test days in a row within a 2-mo period, otherwise 0 . The hypothesis is that high SCC at 2 test days will indicate cows with chronic long-term SCM infection.

Two additional novel SCM traits were defined for SCC thresholds 200 and $400 \times 10^{3}$ cells/mL; SCM200_3 and SCM400_3 were set to 1 if SCC was above the threshold at 3 test days in a row within a 3 -mo period, otherwise 0. By requiring 3 test days with high SCC, which indicates stronger, more long-lasting chronic SCM cases, we assume these traits will identify cows unable to overcome chronic subclinical mastitis, neither going into a clinical phase nor able to reduce SCC in milk.

The number of days from calving to the first case of 2 test-day SCC records above 50 or $400 \times 10^{3}$ cells $/ \mathrm{mL}$ during a 2-mo period were defined as D50 and D400, respectively. These traits are of interest because they could give information on how long cows can stay uninfected without any increase in SCC. We assume that cows who stay longer with SCC below $50 \times 10^{3}$ cells/ $\mathrm{mL}$ have better ability to resist chronic SCM compared with other cows. Thus, these traits can provide additional information for genetic evaluations and indicate cows with either better or worse ability to get SCM for a prolonged period of time.

Additionally, LSCS (the lactation-average SCS; $\log _{\mathrm{e}}$ SCC; Schukken et al., 1992) was included in the analysis. The mean frequencies for the alternative SCM traits from first to third lactation based on $559,988,401,848$, and 247,292 phenotypic records, respectively, for data set $\mathrm{A}$ and $163,513,119,727$, and 73,963 for data set B are given in Table 1 . The mean 305 -d milk yield was $7,441 \mathrm{~kg}$ in data set $\mathrm{A}$ and $7,844 \mathrm{~kg}$ in data set B.

\section{Statistical Analyses}

Software packages SAS, version 9.4 (SAS Inst. Inc., Cary, NC) and DMU (Madsen and Jensen, 2013) were used to perform editing and genetic analyses, respec- 
tively. The pedigree files were built by the DmuTrace software (Madsen, 2012). (Co)variance components were estimated with REML using the DMUAI program (Madsen and Jensen, 2013). Heritability was estimated by single trait repeatability models, whereas genetic correlations between the traits were estimated using bivariate models.

The following linear animal repeatability model was used for estimation of the variance components for all the SCM traits:

$$
\begin{gathered}
y=\text { year_month }+ \text { age }+ \text { days_open }+ \text { herd_year } \\
+ \text { pe }+ \text { animal }+e,
\end{gathered}
$$

where $y$ is the observations for each trait, year_month is the fixed effect of calving year/month (A: 396 levels: 2006.01 to 2016.12; B: 108 levels: 2,014.01 to 2,016.12), age is the fixed effect of age at calving in months by lactation number (58 levels: from 19 to 63 mo during 1-3 lactations), days_open is the fixed effect of days open (i.e., calving-to-conception interval; number of days from 20 to 150 grouped each $10 \mathrm{~d}$ for each lactation), herd_year is the random effect of herd year (A: 49,860; B: 13,450 levels), pe is the permanent environmental effect of repeated cow measurements, animal is the additive genetic effect of animal, and $e$ is the residual. An exception was made for the LSCS trait, by changing the herd_year effect to fixed in the model.

Heritability was calculated using the formula

$$
\mathrm{h}^{2}=\frac{\sigma_{g}^{2}}{\sigma_{g}^{2}+\sigma_{h y}^{2}+\sigma_{p e}^{2}+\sigma_{e}^{2}},
$$

where $\sigma_{g}^{2}$ is the estimated genetic variance, and $\sigma_{h y}^{2}, \sigma_{p e}^{2}$, and $\sigma_{e}^{2}$ are the estimated herd-year, permanent environmental, and residual variance, respectively.

Genetic correlations between the traits were calculated by the following formula:

$$
\operatorname{corr}=\frac{\operatorname{Cov}\left(g_{1}, g_{2}\right)}{\sqrt{\sigma_{g 1} \sigma_{g 2}}},
$$

where $\operatorname{Cov}\left(g_{1}, g_{2}\right)$ is covariance between 2 traits and $\sqrt{\sigma_{g 1} \sigma_{g 2}}$ is the geometric mean of standard deviations for those traits.

Standard errors (SE) estimated from asymptotic SE calculated by DMU, based on the AI-information matrix including the asymptotic correlation matrix parameter vector.

\section{RESULTS AND DISCUSSION}

\section{Descriptive Statistics}

The mean frequency of the SCM traits ranged from 0.8 to $64.7 \%$, presented in Table 1 . For all traits, the

\begin{tabular}{|c|c|c|c|c|c|c|c|c|}
\hline Trait & \multicolumn{4}{|c|}{$\begin{array}{c}\mathrm{A}, \\
\text { test-day SCC records } \\
(2006-2016)\end{array}$} & \multicolumn{4}{|c|}{$\begin{array}{c}\text { B, } \\
\text { test-day SCC records } \\
(2014-2016)\end{array}$} \\
\hline SCM50, \% & 41.6 & 57.6 & 64.5 & 51.6 & 41.5 & 57.8 & 64.7 & 51.8 \\
\hline SCM100, \% & 23.8 & 35.9 & 42.7 & 31.7 & 23.8 & 36.4 & 43.5 & 32.1 \\
\hline SCM150, \% & 15.3 & 24.1 & 29.7 & 21.2 & 15.4 & 24.6 & 30.7 & 21.7 \\
\hline SCM300, \% & 5.6 & 9.6 & 12.5 & 8.3 & 5.8 & 9.9 & 13.3 & 8.7 \\
\hline SCM $350, \%$ & 4.3 & 7.5 & 9.9 & 6.5 & 4.5 & 7.8 & 10.5 & 6.9 \\
\hline SCM $400, \%$ & 3.4 & 5.9 & 8.0 & 5.2 & 3.6 & 6.3 & 8.4 & 5.5 \\
\hline SCM200_3, \% & 3.1 & 5.1 & 6.5 & 4.5 & 4.1 & 6.7 & 8.7 & 5.9 \\
\hline SCM400_3,\% & 0.8 & 1.4 & 1.9 & 1.2 & 1.0 & 1.8 & 2.5 & 1.6 \\
\hline $\mathrm{D} 50, \mathrm{~d}$ & 104 & 106 & 104 & 105 & 104 & 105 & 103 & 104 \\
\hline D400, d & 123 & 115 & 114 & 117 & 124 & 116 & 113 & 117 \\
\hline
\end{tabular}
frequency increased with higher lactation number, but

Table 1. The mean frequency of alternative chronic subclinical mastitis (SCM) traits, ${ }^{1}$ mean lactation-average somatic cell score (LSCS), and 305-d milk yield overall and for lactation 1 to 3 (1st, 2nd, and 3rd) in data sets A and B

${ }^{1}$ Traits: SCM50, SCM100, SCM150, SCM200, SCM250, SCM300, SCM350, and SCM400 = subclinical mastitis above the threshold in 2 test days at 50,000, 100,000, 150,000, 200,000, 250,000, 300,000, 350,000, and 400,000 cells/mL, respectively; SCM200_3 and SCM400_3 = subclinical mastitis traits above the threshold of 200,000 or 400,000 in 3 test days; D50 and D400 = number of days before the first case with SCM 50 and SCM400, respectively; LSCS = lactation-average somatic cell score; milk yield = milk production during $305 \mathrm{~d}$. 
decreased with higher SCC threshold. The mean number of days before the first case with 2 test-day SCC $>50,000$ or SCC $>400,000$ was similar across parities, with range of 103 to 106 and 113 to $124 \mathrm{~d}$, respectively. Mean LSCS increased from 4.3 in 1st lactation to 4.6 in 3rd lactation, corresponding to 72,000 and 100,000 cells/mL. The mean frequency of SCM, based on SCC threshold 50,000 to 200,000, corresponded with the results reported for NR by Svendsen and Heringstad (2006). The highest frequency for SCM50 follows directly from the definition. The lowest frequency was calculated for SCM200_3 and SCM400_3 because of the requirement of 3 test days in a row above the fixed threshold; moreover, the risk of culling increase with high SCC and the frequency may be underestimated. The number of days before SCM50 and SCM400 displays small variation between lactations, but increases with higher threshold. Number of days varies from 21 to 289 (D50) and 21 to 288 (D400).

\section{Heritability}

The estimated heritabilities presented in Table 2, ranged from 0.04 (SCM400) to 0.12 (SCM100), with SE of 0.002 , across SCM traits based on 2 SCC test days. For SCM200_3 and SCM400_3, based on 3 SCC test days, the heritability (SE) was $0.04(0.002)$ and 0.01 (0.001), for D50 and D400 it was $0.02(0.001)$ and 0.01 (0.001), respectively. For LSCS and 305-d milk yield the heritability was $0.26(0.003)$ and $0.26(0.002)$. The estimated heritability of SCM150 was the same as reported for Canadian Holsteins (Koeck et al., 2012). Slightly higher heritability for SCC150 (0.14) was reported for Swedish Holsteins (Urioste et al., 2012) and lower (0.09) for Italian Holsteins (Bobbo et al., 2018). Our results were in agreement with estimated heritabilities reported for SCM in NR based on test-day SCC thresholds of 50 to $200 \times 10^{3}$ cells $/ \mathrm{mL}$ for each of the 3 first lactations, where heritability varied from 0.05 for threshold 200,000 to 0.09 for 50,000 cells $/ \mathrm{mL}$ (Svendsen and Heringstad, 2006). For LSCS, previous estimated heritabilities for NR vary from 0.11 (Ødegård et al., 2004) to 0.17 (Haugaard et al., 2013). For other populations, such as Finnish dairy cattle (Ayrshire and Holstein-Friesian), Austrian Fleckvieh cows, and Holstein-Friesians, LSCS heritabilities of 0.19 (Luttinen and Juga, 1997) and 0.13 (de Haas et al., 2008; Koeck et al., 2010) have been reported. However, SCM traits were defined as binary and variance components estimated by linear models. Heritability estimated on binary traits from linear models depends on frequency, and results from different studies therefore cannot be compared directly. Moreover, SCM can be caused by several different bacterial species giving different SCC.
Haugaard et al. (2013) showed that mastitis caused by different pathogens is not the same trait genetically and have different heritabilities. Subclinical mastitis caused by $S$. aureus had a heritability of 0.04 , whereas mastitis caused by Streptococcus uberis or unspecific had a heritability of 0.11 . The variation in the heritability found in the current study may indicate differences in the causative pathogen and association with different threshold.

\section{Genetic Correlation}

Estimated genetic correlations among the SCM traits are presented in Table 2. High genetic correlations were observed among the SCM traits, with low SE from 0.001 to 0.06 . An unfavorable low or moderate genetic correlation was found to milk yield $(0.07-0.34)$. The correlation between LSCS and milk yield was 0.07, which is in agreement with a correlation of 0.08 reported by Luttinen and Juga (1997) for Finnish dairy cattle. However, a weighted average genetic correlation between SCC and milk production of 0.14 was reported in a review (Mrode and Swanson, 1996). The high genetic correlations among SCM traits corresponded to a previous study for NR (Svendsen and Heringstad, 2006). In other studies, genetic correlations between SCM and alternative SCC traits have been reported to range from a negative favorable correlation such as -0.85 to positive 0.99 (de Haas et al., 2008; Windig et al., 2010; Urioste et al., 2012). A high genetic correlation close to 1 indicates that the same genetic mechanisms affect the traits, otherwise lower genetic correlation indicates that even if traits have some common background they are not exactly the same genetically. The high genetic correlation between SCM50 and LSCS reveals that the threshold of 50,000 cells $/ \mathrm{mL}$ is most similar to LSCS in the NR population, the trait used in the current genetic evaluation of NR. The D50 trait, based on the same threshold of 50,000 cells/mL, showed lower genetic correlations to other alternative SCM traits with variation from 0.67 to 0.93 . The threshold of 400,000 was most different from LSCS and showed the highest (moderate) unfavorable genetic correlation with milk yield. This corresponds to loss in milk production caused by SCM as reported by Hagnestam-Nielsen et al. (2009) and reviewed by Ruegg (2017).

Genetic correlation to $\mathrm{CM}$ was not estimated in the current study; however, a positive genetic correlation between SCC and CM was reported previously by several authors (e.g., Lund et al., 1999; de Haas et al., 2008). Svendsen and Heringstad (2006) estimated genetic correlations ranging from 0.26 to 0.62 between $\mathrm{CM}$ and SCM traits, and found a stronger correlation between SCM based on higher threshold of SCC and 
SUBCLINICAL MASTITIS TRAITS FOR GENETIC EVALUATION

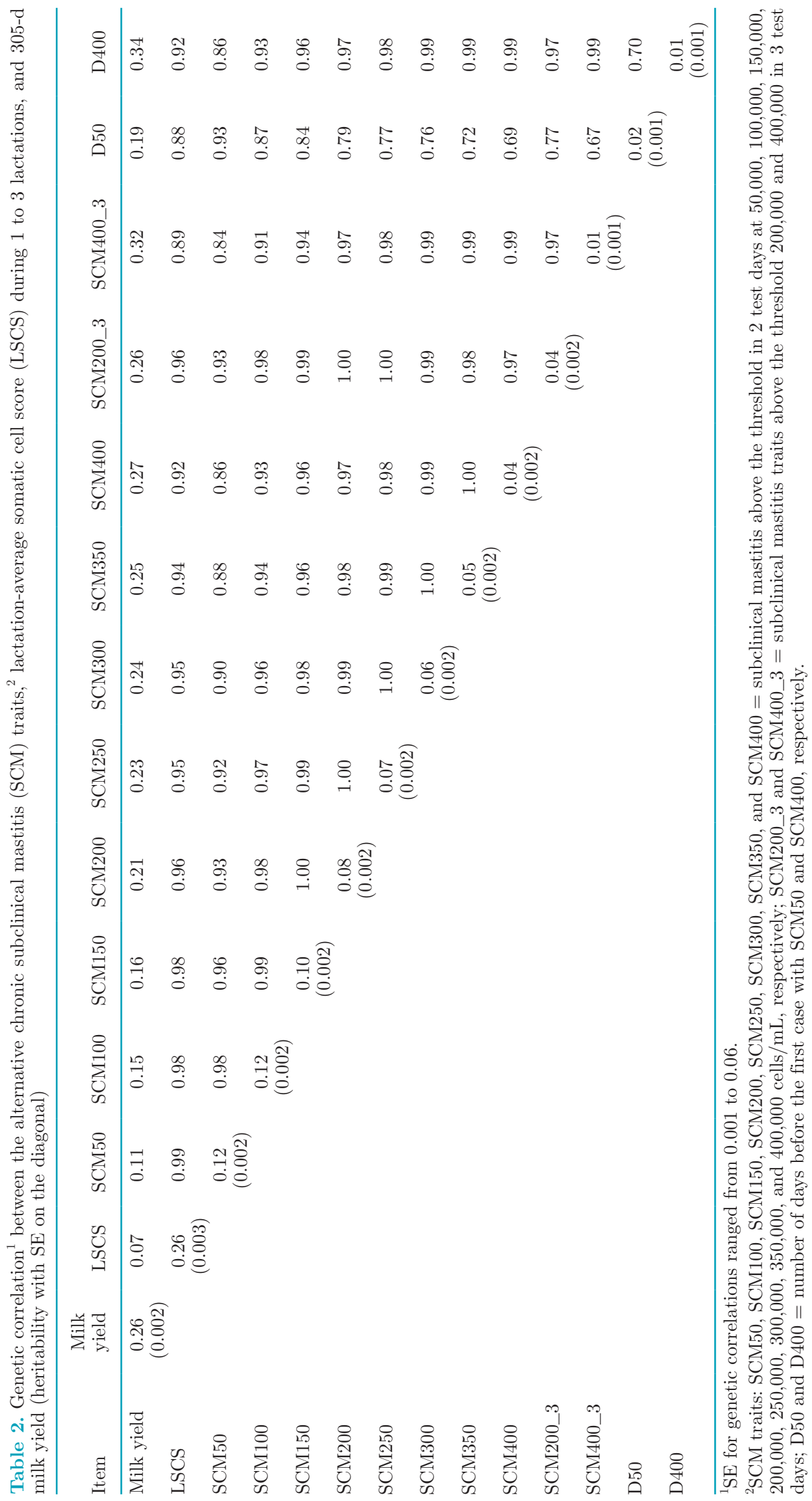


CM in late lactation. Haugaard et al. (2012, 2013) estimated genetic correlations lower than 1 between pathogen-specific CM and SCM in NR dairy cows and concluded that they should be considered as partly different traits.

\section{Trait Definitions}

The definition of the traits in the current study were based on previous genetic analyses of SCC and SCM in the NR population (Svendsen and Heringstad, 2006). Eight SCC thresholds from 50,000 to 400,000 cells/mL were evaluated. A healthy mammary gland usually has a SCC below 50,000 cells (Barbano et al., 2006), but is often defined as SCC $<100,000$ cells $/ \mathrm{mL}$ (Schwarz et al., 2011). The discussion on possible effects of too low SCC in bovine milk has increased in recent years (Rainard et al., 2018). For example, Schalm et al. (1971) reported that any mid-lactation milk samples with SCC $>20,000$ cells/mL are a sign of inflammation. Other studies considered SCC $<100,000$ cells $/ \mathrm{mL}$ to be defined as healthy quarters (Schwarz et al., 2011) and others use below 200,000 cells/mL (Schepers et al., 1997; Pantoja et al., 2009). Sarikaya et al. (2006) reported that SCC in healthy quarters consists mostly of immune cells, such as lymphocytes and macrophages, whereas in case of increased SCC all inflammatory factors will increase. Several authors concluded that alternatively defined SCC traits provide additional information that may improve genetic evaluation and selection on mastitis resistance and udder health (de Haas et al., 2008; Windig et al., 2010; Koeck et al., 2012; Bobbo et al., 2018). The SCC limit of 400,000 cells/mL in bovine milk allowed for human consumption was applied by the European Commission Milk Hygiene Directive (92/46) in 1992 and used as the upper limit in the current study. To identify chronic SCM cases, 2 and 3 subsequent SCC records were evaluated. The number of affected cows with SCC above 200,000 cells $/ \mathrm{mL}$ was reduced from $14.9 \%$ (SCM200) to $4.5 \%$ (SCM200_3) between 2 and 3 subsequent test day records, respectively, and from $5.2 \%$ (SCM400) to $1.2 \%$ (SCM400_3) for 400,000 cells/mL. The main reason for the very low frequency of SCM with 3 test days with high SCC in the NR population is probably censoring (i.e., culling of cows with high SCM) because SCM led to reduced milk production followed by economic loss. Moreover, by doubling SCC above 50,000 cells $/ \mathrm{mL}$, production losses of 91 and $181 \mathrm{~kg}$ of milk per lactation for parity 1 and $>1$, respectively, will be expected (reviewed by Ruegg, 2017). Low frequency will affect the estimated parameters as mentioned above, but by requiring 3 subsequent test days with high SCC we will identify stronger cases with chronic inflammations and possibly have a more precise definition of chronic SCM cases. Traits D50 and D400 take the time aspect into account, namely how long cows can stay with SCC below 50,000 cells $/ \mathrm{mL}$ or below 400,000 cells $/ \mathrm{mL}$. A higher number of days indicates better ability to resist SCM. The number of days for D50 displayed little or no variation between parities, indicating no effect of lactation number on the D50 trait. However, for D400 the number of days was lower with increased lactation number and compared with D50 were higher on average. Several of the alternative SCM traits (D50, D400, and SCM400_3) included in the current study are novel in definition. Relatively high frequency and lower correlation to the other traits indicate that these novel traits should be taken into account to improve breeding strategies against chronic SCM. However, udder health is a complex trait and further research is needed before we can make any recommendations on how to combine the many aspects of udder health in a selection index.

\section{CONCLUSIONS}

The 12 alternatively defined traits for chronic SCM display genetic variation, and the estimated genetic correlations among the traits were strong. The trait used in genetic evaluation for NR, LSCS, had the highest genetic correlation with SCM50, whereas milk yield had the strongest unfavorable genetic correlation with SCM400_3 and D400, which were the most different from the LSCS trait. Based on the genetic correlations that were lower than 1, all traits can be considered as partly different traits, which provide additional information on chronic subclinical mastitis and may be used for genetic evaluation to improve breeding for better udder health.

\section{ACKNOWLEDGMENTS}

Geno Breeding and AI Association (Hamar, Norway) and the Norwegian Dairy Herd Recording System are acknowledged for providing access to data. This work is part of the "Multimast" project (no. 233778) funded by the Research Council of Norway, Tine, and Geno and coordinated by Norwegian University of Life Sciences (NMBU).

\section{REFERENCES}

Barbano, D. M., Y. Ma, and M. V. Santos. 2006. Influence of raw milk quality on fluid milk shelf life. J. Dairy Sci. 89(Suppl 1):E15-E19. https://doi.org/10.3168/jds.S0022-0302(06)72360-8.

Begley, N., F. Buckley, K. M. Pierce, A. G. Fahey, and B. A. Mallard. 2009. Differences in udder health and immune response traits of Holstein-Friesians, Norwegian Reds, and their crosses in second lactation. J. Dairy Sci. 92:749-757. https://doi.org/10.3168/jds .2008-1356. 
Bobbo, T., M. Penasa, R. Finocchiaro, G. Visentin, and M. Cassandro. 2018. Alternative somatic cell count traits exploitable in genetic selection for mastitis resistance in Italian Holsteins. J. Dairy Sci. https://doi.org/10.3168/jds.2018-14827.

de Haas, Y., W. Ouweltjes, J. ten Napel, J. J. Windig, and G. de Jong. 2008. Alternative somatic cell count traits as mastitis indicators for genetic selection. J. Dairy Sci. 91:2501-2511. https://doi.org/ $10.3168 /$ jds.2007-0459.

Dohoo, I. R., and K. E. Leslie. 1991. Evaluation of changes in somaticcell counts as indicators of new intramammary infections. Prev. Vet. Med. 10:225-237. https://doi.org/10.1016/0167-5877(91)90006-N.

Hagnestam-Nielsen, C., U. Emanuelson, B. Berglund, and E. Strandberg. 2009. Relationship between somatic cell count and milk yield in different stages of lactation. J. Dairy Sci. 92:3124-3133. https:/ /doi.org/10.3168/jds.2008-1719.

Harmon, R. J. 1994. Symposium - Mastitis and genetic evaluation for somatic cell count - Physiology of mastitis and factors affecting somatic cell counts. J. Dairy Sci. 77:2103-2112. https://doi.org/10 .3168/jds.S0022-0302(94)77153-8.

Haugaard, K., B. Heringstad, and A. C. Whist. 2012. Genetic analysis of pathogen-specific clinical mastitis in Norwegian Red cows. J. Dairy Sci. 95:1545-1551. https://doi.org/10.3168/jds.2011-4522.

Haugaard, K., B. Heringstad, and A. C. Whist. 2013. Genetic associations between somatic cell score and pathogen-specific subclinical mastitis in Norwegian Red cows. J. Anim. Breed. Genet. 130:98105. https://doi.org/10.1111/jbg.12019.

Koeck, A., B. Heringstad, C. Egger-Danner, C. Fuerst, P. Winter, and B. Fuerst-Waltl. 2010. Genetic analysis of clinical mastitis and somatic cell count traits in Austrian Fleckvieh cows. J. Dairy Sci. 93:5987-5995. https://doi.org/10.3168/jds.2010-3451.

Koeck, A., F. Miglior, D. F. Kelton, and F. S. Schenkel. 2012. Alternative somatic cell count traits to improve mastitis resistance in Canadian Holsteins. J. Dairy Sci. 95:432-439. https://doi.org/10 $.3168 /$ jds.2011-4731.

Lund, M. S., J. Jensen, and P. H. Petersen. 1999. Estimation of genetic and phenotypic parameters for clinical mastitis, somatic cell production deviance, and protein yield in dairy cattle using Gibbs sampling. J. Dairy Sci. 82:1045-1051. https://doi.org/10.3168/jds .S0022-0302(99)75325-7.

Luttinen, A., and J. Juga. 1997. Genetic relationships between milk yield, somatic cell count, mastitis, milkability and leakage in Finish dairy cattle population. Interbull Bull. 15:78-83.

Madsen, P. 2012. DmuTrace. A program for extracting the pedigree for a subset of animals from a larger pedigree. Version 2. Aarhus University, Aarhus, Denmark.

Madsen, P., and J. Jensen. 2013. A User's Guide to DMU. A Package for Analysing Multivariate Mixed Models. Version 6, release 5.2. Aarhus University, Aarhus, Denmark.

Miller, R. H., M. J. Paape, and L. A. Fulton. 1991. Variation in milk somatic cells of heifers at first calving. J. Dairy Sci. 74:3782-3790. https://doi.org/10.3168/jds.S0022-0302(91)78570-6.

Mrode, R., and G. Swanson. 1996. Genetic and statistical properties of somatic cell count and its suitability as an indirect means of reducing the incidence of mastitis in dairy cattle. Animal Breeding Abstracts (United Kingdom).

Ødegård,, J., B. Heringstad, and G. Klemetsdal. 2004. Short communication: bivariate genetic analysis of clinical mastitis and somatic cell count in Norwegian dairy cattle. J. Dairy Sci. 87:3515-3517. https://doi.org/10.3168/jds.S0022-0302(04)73487-6.

Østerås, O., H. Solbu, A. O. Refsdal, T. Roalkvam, O. Filseth, and A. Minsaas. 2007. Results and evaluation of thirty years of health recordings in the Norwegian dairy cattle population. J. Dairy Sci. 90:4483-4497. https://doi.org/10.3168/jds.2007-0030.

Pantoja, J. C., C. Hulland, and P. L. Ruegg. 2009. Dynamics of somatic cell counts and intramammary infections across the dry period. Prev. Vet. Med. 90:43-54. https://doi.org/10.1016/j.prevetmed 2009.03.012.

Rainard, P., G. Foucras, D. Boichard, and R. Rupp. 2018. Invited review: Low milk somatic cell count and susceptibility to mastitis. J. Dairy Sci. 101:6703-6714. https://doi.org/10.3168/jds.2018-14593.

Ruegg, P. L. 2017. A 100-Year Review: Mastitis detection, management, and prevention. J. Dairy Sci. 100:10381-10397. https://doi .org/10.3168/jds.2017-13023.

Sarikaya, H., G. Schlamberger, H. H. Meyer, and R. M. Bruckmaier. 2006. Leukocyte populations and mRNA expression of inflammatory factors in quarter milk fractions at different somatic cell score levels in dairy cows. J. Dairy Sci. 89:2479-2486. https://doi.org/ 10.3168/jds.S0022-0302(06)72322-0.

Schalm, O. W., E. J. Carroll, and N. C. Jain. 1971. Number and types of somatic cells in normal and mastitic milk. Pages 94-127 in Bovine Mastitis. Lea \& Febiger, Philadelphia, PA.

Schepers, A. J., T. J. Lam, Y. H. Schukken, J. B. Wilmink, and W J. Hanekamp. 1997. Estimation of variance components for somatic cell counts to determine thresholds for uninfected quarters. J. Dairy Sci. 80:1833-1840. https://doi.org/10.3168/jds.S0022 -0302(97)76118-6.

Schukken, Y. H., K. E. Leslie, A. J. Weersink, and S. W. Martin. 1992. Ontario bulk milk somatic cell count reduction program. 2. Dynamics of bulk milk somatic cell counts. J. Dairy Sci. 75:3359 3366. https://doi.org/10.3168/jds.S0022-0302(92)78112-0.

Schwarz, D., U. S. Diesterbeck, S. Konig, K. Brugemann, K. Schlez, M. Zschock, W. Wolter, and C. P. Czerny. 2011. Microscopic differential cell counts in milk for the evaluation of inflammatory reactions in clinically healthy and subclinically infected bovine mammary glands. J. Dairy Res. 78:448-455. https://doi.org/10 1017/S0022029911000574.

Svendsen, M., and B. Heringstad. 2006. Somatic cell count as an indicator of sub-clinical mastitis. Genetic parameters and correlations with clinical mastitis. Interbull Bull. 35:12-16.

TINE. 2017. TINE Rådgivning. Statistikksamling 2017 [TINE Annual Statistics 2017]. Accessed October 12, 2018. https://medlem.tine .no/fagprat/helse/_attachment/427411?_ts=16167bec8ab. (in Norwegian, with English Tables).

Urioste, J. I., J. Franzen, J. J. Windig, and E. Strandberg. 2012. Genetic relationships among mastitis and alternative somatic cell count traits in the first 3 lactations of Swedish Holsteins. J. Dairy Sci. 95:3428-3434. https://doi.org/10.3168/jds.2011-4739.

Windig, J. J., W. Ouweltjes, J. Ten Napel, G. de Jong, R. F. Veerkamp, and Y. De Haas. 2010. Combining somatic cell count traits for optimal selection against mastitis. J. Dairy Sci. 93:1690-1701. https: //doi.org/10.3168/jds.2009-2052. 